\title{
ANÁLISIS
}

\section{Pacific Alliance: \\ Bringing Back Open Regionalism to Latin America}

DOI: $10.32870 /$ mycp.v4i11.483

\author{
Maria Alejandra Gonzalez-Perez ${ }^{1}$ \\ Santiago Gutiérrez-Viana ${ }^{2}$ \\ Juan David Rodríguez Rios ${ }^{3}$ \\ Laura Gutiérrez Gómez ${ }^{4}$
}

\begin{abstract}
This paper seeks to answer why the Pacific Alliance (PA) has emerged as the latest integration initiative in the already wide spectrum of multilateral
\end{abstract}

Artículo recibido el 24 de octubre de 2014 y dictaminado el 15 de diciembre de 2014.

1. Universidad EAfit, Full Professor of Management, Medellin, Colombia. She is the coordinator of Colombian universities to the virtual institute of the United Nations Conference for Trade and Development (UNCTAD), and representative of the Americas universities to the Pacific Asia Consortium for International Business Education and Research (PACIBER). Email: mgonza40@eafit. edu.co Universidad EAfit, Business School. Cra 49 núm. 7 Sur 50. Bl. 26-416. Medellin, Colombia.

2. Executive Director of The Latin Trade Group, Miami, Estados Unidos. Former Editor-in-chief of Revista Dinero.com, and Nota Económica in Colombia. He was also Associate Researcher at Fedesarrollo, and Vice President of Colombian Banking Association. Email: s.gutierrez.vt@gmail.com

3. Universidad EAfIT, International Negotiator, Medellin, Colombia. Currently student in the Master of Public Policy at National Graduate Institute for Policy Studies in Japan. Associate member of the Group in International Studies at Universidad EAFIT and former advisor to the Directorate of Asia, Africa and Oceania at the Ministry of Foreign Affairs of Colombia. Email: jrodri26@eafit.edu.co

4. Jurist from Maastricht University, Netherlands and Master (Cum Laude) in Criminology from Utrecht University. She worked as junior researcher at Utrecht University; as legal researcher in cases regarding EU market access and trade remedies; and legal intern in Brigard \& Urrutia Abogados, within the team of Forex, Derivatives and Structured Finance. She is currently a research assistant at Fedesarrollo in Colombia, and a Master's student (MPhil in Criminology) at Cambridge University. Email: gutierrezlaura2@gmail.com 
groups in Latin America. It does so by evaluating the political and economic considerations that motivated the PA's formation, aiming to present informed arguments within the framework of trade and political developments in the region. This paper is based on both secondary and primary data (interviews), and it is divided into four parts plus conclusions. The paper starts by presenting a general characterization of the Alliance; afterwards, presents a historic and comparative overview of the integration processes in the region; assesses the current level of integration between the PA members; and, finally, offers insights into future developments in the following areas: transnational production chains, access to foreign markets and extra-regional (economic and political) outreach. The results of this study show how the public and private sector's experience in international trade and international business has motivated the members of the Pacific Alliance to join forces to consolidate a platform for economic integration allowing them to increase market access, foster economic growth, and improve human development indicators in the region. From the political point of view, the paper concludes that the PA emerged as a liberal counterpart to the left-leaning integration initiatives that had been prevalent in the region during the preceding decade.

Keywords: Pacific Alliance, economic integration, Latin America, trade, regional politics.

\section{LA Alianza del PACífico: el Regreso del Regionalismo ABIERTO A AMÉRICA LATINA}

\section{Resumen}

En el presente artículo se busca responder por qué la Alianza del Pacífico (AP) ha surgido como la más reciente iniciativa dentro del ya amplio espectro de agrupaciones multilaterales en América Latina. Para ello, en el documento se evalúan las consideraciones políticas y económicas que motivaron la formación de la AP, presentando argumentos informados en el marco de los desarrollos comerciales y políticos en la región. Este documento se basa en fuentes tanto primarias (entrevistas) como secundarias y se divide en cuatro secciones, más conclusiones. En primer lugar se presenta una caracterización general de la Alianza del Pacífico; en seguida se presenta un resumen histórico y comparativo de la AP con otras iniciativas regionales de integración; se evalúa el grado de integración que se ha alcanzado hasta el momento entre los países miembros 
de la AP, y finalmente se ofrecen perspectivas sobre los futuros desarrollos en las siguientes áreas: cadenas transnacionales de valor, acceso a mercados extranjeros y diversificación de las relaciones económicas y políticas de sus miembros. Los resultados de este estudio sugieren que la experiencia de los sectores público y privado en materia de comercio intrarregional motivó a los países de la Alianza a aunar esfuerzos para consolidar una plataforma de integración económica que les permitiese potenciar el acceso a mercados, fortalecer el crecimiento económico y mejorar los indicadores de desarrollo humano en la región. Desde el punto de vista político, el documento concluye que la AP surgió como una alternativa liberal frente a las iniciativas de integración de corte izquierdista que fueron prevalentes en la década precedente.

Palabras clave: Alianza del Pacífico, integración regional, Latinoamérica, comercio, política regional.

\section{Introduction}

The Pacific Alliance (PA) is a Latin American regional economic integration platform and trade facilitating mechanism comprised by four fast growing, market oriented and attractive for FDI economies: Chile, Colombia, Mexico and Peru, which was established on April 2011 in Lima. The joint population of the four member countries accounts for over one-third of the total population in Latin America and, when aggregated, their economy is the 9th largest in the world (Dade \& Meacham, 2013). Led by the initiative of Peruvian President Alan García Pérez, the Pacific Alliance was created with the aim of developing a common trade area in order to deepen economic and market integration, and enhance commercial and political relations with Asia (Declaración de Lima, 2011). PA's Framework agreement was formally signed the 6th of June 2012 by Presidents of Chile, Colombia, Mexico and Peru at the Paranal astronomical observatory located at the south of Antofagasta in Chile (Declaración de Paranal, 2012).

The Pacific Alliance was built up on the initiative called "The Arch of the Pacific" (Foro sobre la Iniciativa de la Cuenca del Pacífico Latinoamericano) which was launched on January 2007 in Cali-Colombia with the participation of Chile, Colombia, Costa Rica, Ecuador, El Salvador, Guatemala, Honduras, Mexico, Nicaragua, Panama and Peru. The main objective of The Arch of the Pacific was to enhance competitiveness through commercial and economic 
cooperation amongst members and stimulate trade with Asia. However, nothing concrete resulted from the ministerial meetings of this particular initiative (Dade \& Meacham, 2013).

This paper is based on both secondary and primary data (interviews), and it is divided into five parts. On the first section, the background of the emergence of the Pacific Alliance based on contextual aspects both in the Latin American region and in the rest of the world are be presented. The second part of the paper, analyses the economic and political dimensions of the PA. The third section, describes how the dynamics of the PA have been mutually influenced by private and public sector initiatives, and presents how the corporate sector might benefit of this process. And finally, the fifth section, encapsulates an analysis on the future of the Pacific Alliance, focusing on aspects such as potential market access, and balance of powers unveiled in the region associated with the launch and consolidation of the Alliance.

\subsection{International context and trade integration processes in Latin America}

The processes of liberalising national economies, the increased relevance of international finance and trade, and the internationalisation of corporate structures, contributed to the rapid establishment of internationally integrated market structures. These have been complemented with incentives to formalise and institutionalise economic cooperation agreements (Colleman \& Underhill, 1998; Jessop, 2013). Nonetheless, there is limited evidence of thorough international integration, and increasing scepticism about perfect global integration in markets for goods, services and factors of production (Krapohl \& Fink, 2013; Murray \& Moxon-Browne, 2013; Rodrik, 2000).

Since the 1970s barriers to international flows of goods and services have been lowered, but there is still disbelief about universal integration. Some of the reasons that explain this scepticism are: differences in national development stages; impossibility to have template contracts in different jurisdictions (thereby increasing the risk of opportunism); limitations on people and capital mobility between poor and rich countries; weak predictability of interest rates; preference of investors from developed countries for portfolio investments in their own countries; existence of tariff and non-tariff barriers (NTB); and the international arbitration of commodity prices, among others.

Since the early 1990s the world has seen a proliferation of Free Trade Agreements (FTAs) (Gonzalez, 2009; Park, Urata \& Cheong 2007). However, 
conclusions as to whether FTAs affect economic growth vary. Researchers such as Baier and Bergstrand (2007) and Sohn and Lee (2010) identified a positive relationship with economic growth; while other authors (François, McQueen \& Wignaraja, 2005; Richardson, 1993) show that FTAs increase trade imbalances between the countries, with disadvantages for developing countries.

As described by the WTO (2011), the world has increased the number of preferential trade agreements in the last two decades by over 400 percent. Currently the organization reports more than 300 such agreements. This might be caused by international economic dynamics, in which FTAs are preferred either because there is a herd effect at the regional level (Baldwin \& Jaimovich, 2012), or because there is an extended scepticism about WTO's multilateral trading system (Bhagwati, 2008; Busch \& Reinhardt, 2003).

This growth of preferential trade agreements might also be explained by tendencies towards regionalism, strong since the 1950s in Western Europe, followed by initiatives in Africa, Asia and Latin America in the 1980s.

\subsection{Regional background}

In Latin America and the Caribbean the growth of FTAs might also be explained by a generalized disbelief in sub regional trade agreements (Baker \& Greene, 2011; Dade \& Mecham, 2013; Darnton, 2012; Malamud, 2005; Malamud, 2012; Mecham, 2003). Historically, the first market integration initiative in the region was the Central American Common Market (CACM) in 1958 (Bulmer-Thomas, 1998). This agreement intended to facilitate development by generating economies of scale in production and distribution of non-traditional exports from member countries - Costa Rica, El Salvador, Guatemala, Honduras and Nicaragua-. This would encourage agricultural diversification, and promote industrialization.

After this initiative, the Latin American Free Trade Association (LAFTA) was created in 1960 aiming to stimulate intra-regional trade (Haas, 1965; Milenky, 1973). Nonetheless, less favoured countries in the region were dissatisfied with the LAFTA and considered that the benefits of this agreement were unevenly distributed and that they were not contributing to economic development. This discontentment motivated the negotiation of the Andean Pact in 1969 - Bolivia, Colombia, Chile, Ecuador and Peru (Venezuela signed in 1974 and Chile withdrew in 1976) —, which eliminated intra-regional trade barriers, and established a common external tariff (Hojman, 1981; Vargas- 
Hidalgo, 1979). These attempts resulted in failures, and profound market integration among their members was not achieved (Garman \& Gilliard, 1998).

Since its inception, in the year 2000, Mercosur tried to foster SouthSouth trade relations, and there is evidence which demonstrates an increase in trade volume and investment flows, as well as an increase in value-added exports in the trade area. However, recently the agreement has shown limitations and has failed to advance towards a functioning customs union (Celli, Salles, Tussie \& Peixoto, 2010). Mercosur has had a limited progress in some areas, including social and political dimensions. Peña \& Rozemberg (2010) and UNCTAD (2010) pointed out that the excessive power exercised by Brazil over other members has caused an imbalance in negotiations and therefore has limited the implementation of agreements in Mercosur. Also, both the instability in macroeconomic structures and the long history of commercial disputes between Argentina and Brazil have negatively affected Mercosur.

The following table presents chronologically the Latin America and Caribbean intra-regional trading blocs.

\section{Table 1}

Latin America and Caribbean's intra-regional trading blocs

\begin{tabular}{l|l|l}
\hline $\begin{array}{l}\text { Date of } \\
\text { Creation }\end{array}$ & Initiative & Member Countries \\
\hline 1951 & $\begin{array}{l}\text { Organization of Central } \\
\text { American States }\end{array}$ & Guatemala, Costa Rica, Honduras, El Salvador. \\
\hline 1960 & $\begin{array}{l}\text { Central America } \\
\text { Common Market } \\
\text { (MCCA) }\end{array}$ & $\begin{array}{l}\text { Costa Rica, El Salvador, Guatemala, Honduras, } \\
\text { Nicaragua. }\end{array}$ \\
\hline 1960 & $\begin{array}{l}\text { Latin American Free } \\
\text { Trade Association } \\
\text { (LAFTA/ALALC) }\end{array}$ & $\begin{array}{l}\text { Argentina, Brazil, Mexico, Chile, Uruguay, Paraguay. } \\
\text { Succeeded in 1980 by ALADI. }\end{array}$ \\
\hline 1969 & $\begin{array}{l}\text { Andean Nations } \\
\text { Community (CAN) }\end{array}$ & Bolivia, Ecuador, Colombia, Peru. \\
\hline $\begin{array}{l}\text { Caribbean Community } \\
\text { (Caricom) }\end{array}$ & $\begin{array}{l}\text { Antigua y Barbuda, Bahamas, Belize, Dominica, } \\
\text { Grenada, Guyana, Haiti, Jamaica, Montserrat, St. } \\
\text { Christopher and Nevis, St. Lucia, St. Vincent and } \\
\text { Grenadines, Suriname, Trinidad and Tobago. }\end{array}$ \\
\hline
\end{tabular}


Pacific Alliance: Bringing Back Open Regionalism to Latin America

\begin{tabular}{|c|c|c|}
\hline $\begin{array}{l}\text { Date of } \\
\text { Creation }\end{array}$ & Initiative & Member Countries \\
\hline 1975 & $\begin{array}{l}\text { Latin America and } \\
\text { Caribbean Economic } \\
\text { System }\end{array}$ & $\begin{array}{l}\text { Argentina, Bahamas, Barbados, Belize, Bolivia, } \\
\text { Brazil, Chile, Colombia, Costa Rica, Cuba, Ecuador, } \\
\text { El Salvador, Grenada, Guatemala, Guyana, Haiti, } \\
\text { Honduras, Jamaica, Mexico, Nicaragua, Panama, } \\
\text { Paraguay, Peru, Dominican Republic, Suriname, } \\
\text { Trinidad and Tobago, Uruguay and Venezuela. }\end{array}$ \\
\hline 1980 & $\begin{array}{l}\text { Latin American } \\
\text { Integration Association } \\
\text { (ALADI) }\end{array}$ & $\begin{array}{l}\text { Argentina, Bolivia, Brazil, Chile, Colombia, Cuba, } \\
\text { Ecuador, México, Nicaragua, Panamá, Paraguay, } \\
\text { Uruguay, Venezuela. }\end{array}$ \\
\hline 1981 & $\begin{array}{l}\text { East Caribbean States } \\
\text { Organization }\end{array}$ & $\begin{array}{l}\text { Antigua y Barbuda, Dominica, Grenada, Guyana, } \\
\text { Montserrat, St. Lucia, St. Vincent and Grenadines. }\end{array}$ \\
\hline 1991 & $\begin{array}{l}\text { South Common Market } \\
\text { (Mercosur) }\end{array}$ & Argentina, Brazil, Paraguay, Venezuela, Uruguay. \\
\hline 1993 & $\begin{array}{l}\text { Central American } \\
\text { Integration System }\end{array}$ & $\begin{array}{l}\text { Belize, Costa Rica, El Salvador, Guatemala, Honduras, } \\
\text { Nicaragua, Panama. }\end{array}$ \\
\hline 1994 & $\begin{array}{l}\text { Caribbean States } \\
\text { Association (AEC) }\end{array}$ & $\begin{array}{l}\text { Antigua and Barbuda, Bahamas, Belize, Colombia, } \\
\text { Costa Rica, Cuba, Dominica, El Salvador, Grenada, } \\
\text { Guatemala, Haiti, Honduras, Jamaica, Mexico, } \\
\text { Nicaragua, Panama, Dominican Republic, St. } \\
\text { Christopher and Nevis, St. Lucia, St. Vincent and } \\
\text { Grenadines, Suriname, Trinidad and Tobago, } \\
\text { Venezuela. }\end{array}$ \\
\hline 2004 & $\begin{array}{l}\text { Bolivarian Alliances for } \\
\text { Our America's People } \\
\text { (ALBA) }\end{array}$ & $\begin{array}{l}\text { Antigua and Barbuda, Bolivia, Cuba, Dominica, } \\
\text { Ecuador, Nicaragua, St. Vincent and Grenadines, and } \\
\text { Venezuela. }\end{array}$ \\
\hline 2008 & $\begin{array}{l}\text { Union of South } \\
\text { American Nations } \\
\text { (Unasur) }\end{array}$ & $\begin{array}{l}\text { Argentina, Bolivia, Brazil, Chile, Colombia, Ecuador, } \\
\text { Guyana, Paraguay, Peru, Suriname, Uruguay, and } \\
\text { Venezuela. }\end{array}$ \\
\hline 2010 & $\begin{array}{l}\text { Community of Latin } \\
\text { American and Caribbean } \\
\text { States (CELAC) }\end{array}$ & $\begin{array}{l}\text { Antigua and Barbuda, Argentina, Bahamas, Barbados, } \\
\text { Belize, Bolivia, Brazil, Chile, Colombia, Costa Rica, } \\
\text { Cuba, Ecuador, El Salvador, Grenada, Guatemala, } \\
\text { Guyana, Haiti, Honduras, Jamaica, Mexico, Nicaragua, } \\
\text { Panamá, Paraguay, Peru, Dominican Republic, } \\
\text { Suriname, Trinidad and Tobago, Uruguay, Venezuela. }\end{array}$ \\
\hline 2012 & Pacific Alliance (AP) & Chile, Mexico, Colombia, Peru. \\
\hline
\end{tabular}

Source: Official agreement pages. Table summarized by authors.

The Pacific Alliance (PA) was launched, hence, after nearly 50 years of failed regional and sub-regional integration attempts. Given the examples of regional initiatives with limited achievements, the question of whether this 
The Pacific Alliance (PA) was launched, hence, after nearly 50 years of failed regional and sub-regional integration attempts. Given the examples of regional initiatives with limited achievements, the question of whether this scheme would have the potential of effectively contributing to the sustained development of its members via deepening economic integration, seems valid and still open

scheme would have the potential of effectively contributing to the sustained development of its members via deepening economic integration, seems valid and still open.

Briceño Ruiz (2012: 136) states that the PA is a "third axis of regional integration, which aims to defend the open integration model in Latin America." The reformist character of Mercosur, which includes provisions for strengthening social dimensions and production processes, represents the first axis even though the focus remains on being a trade facilitation instrument. The second axis is represented by Unasur (Union of South American Nations), proposing a non-capitalist integration based on cooperation, solidarity and complementarity. Unlike other regional and subregional agreements, the Lima Declaration — whereby Chile, Colombia, Mexico and Peru agreed to create the Pacific Alliance- declared the intention of the member countries to establish a "deep integration area through a process of political articulation and economic cooperation and integration in Latin America." In addition, the Alliance seeks to be a balance to Brazil's regional leadership, and distances itself from the inward-looking and antiAmerican rhetoric that has been evidenced in the Latin American integration initiatives of the last decade.

\section{Economic and political dimensions of the Pacific Alliance}

Current member countries of the Pacific Alliance have a long regional economic integration record, inspired by the Western European experience (Devlin \& French-Davis, 2002). According to different authors (Ardila, 2012; Mols, 2005; Vargas-Alzate, Sosa \& Rodriguez-Rios, 2012), foreign policy in Latin 
America has been increasingly influenced by aspirations of international trade intensification. But perhaps most striking, as it was found by Vargas-Alzate, Sosa and Rodriguez-Rios (2012), regional trade has deepened Latin American Nations' diplomatic relations.

\subsection{Trade relations and market access}

Pacific Alliance's countries have existing Economic Complementation Agreements among themselves under ALADI (Latin American Integration Association), which is the framework for the integration initiatives in the subcontinent under the enabling clause for developing countries of the WTO. These economic relations have been made more profound as trade was liberalized on a bilateral basis. Colombia and Peru achieved this via the Andean Community of Nations, which also joins Ecuador and Bolivia which are not members of the PA. The most recent free trade agreement (FTA) among member countries was signed in 2012 by Mexico and Peru.

\subsubsection{Goods, services and investment}

Current PA members made 2.8\% (USD 518,170 million) of world imports in 2011 (International Trade Center, 2013). The main exporter to PA countries was the United States. In that year, 41.2\% (almost USD 210 billion) of the combined imports of the four member countries came from the Us. This figure was followed by imports from China that added to $15.2 \%$ of total imports (USD 77.4 billion), and from Japan 4.2\% (almost USD 22 billion) (idem).

The main exported goods by PA members in 2011 were fuels (alcohol for air transportation [4.3\%]; light petroleum distillate [3.5\%]; and crude oils [2.0\%]) (International Trade Center, 2013).

The following table summarizes the previous economic and commercial agreements between Pacific Alliance members.

The technical barriers to trade including sanitary, phytosanitary and technical standards were negotiated within the framework of these agreements. The countries which have deepened their bilateral trade relations the least are Mexico and Peru (López \& Muñoz, 2012). Mexico's position in the FTA with Peru emphasized the protection of its agriculture industry, specifically of coffee, sugar and beef (Morales, 2011). 
Table 2

Previous economic agreements between Pacific Alliance members

\begin{tabular}{|c|c|c|c|c|}
\hline & Colombia & Chile & Peru & Mexico \\
\hline Colombia & & 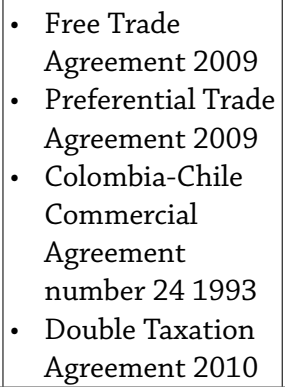 & $\begin{array}{l}\text { - Andean } \\
\text { Nations } \\
\text { Community } \\
\text { (CAN) } 1969 \\
\end{array}$ & $\begin{array}{l}\text { Free Trade } \\
\text { Agreement } \\
2011\end{array}$ \\
\hline Chile & 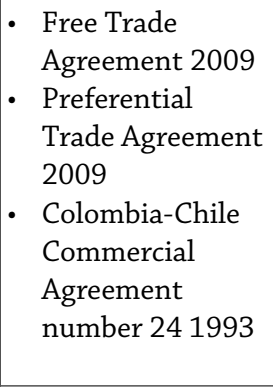 & & \begin{tabular}{|l} 
- Free Trade \\
Agreement \\
2009 \\
- Chile-Peru \\
Commercial \\
Agreement \\
381998
\end{tabular} & \begin{tabular}{|l} 
- Association \\
Agreement \\
1998 \\
- Preferential \\
Trade \\
Agreement \\
2008 \\
- Double Taxation \\
Agreement \\
2000
\end{tabular} \\
\hline Peru & $\begin{array}{l}\text { - Andean Nations } \\
\text { Community } \\
\text { (CAN) } 1969\end{array}$ & 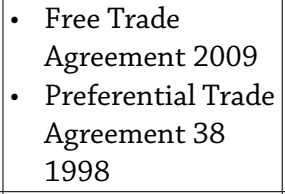 & & $\begin{array}{l}\text { Commercial } \\
\text { Integration } \\
\text { Agreement } \\
2011\end{array}$ \\
\hline Mexico & $\begin{array}{l}\text { - Free Trade } \\
\text { Agreement } 2011\end{array}$ & 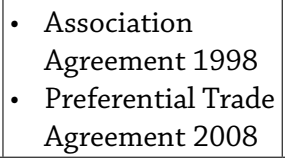 & $\begin{array}{l}\text { - Commercial } \\
\text { Integration } \\
\text { Agreement } \\
2011 \\
\end{array}$ & \\
\hline
\end{tabular}

Source: Adapted from: López \& Muñoz (2012: 20).

Currently Colombia has bilateral agreements with each of the remaining member countries of the PA. On average, Colombia has an aggregate tariff concession of $97 \%$ with the other three countries, and agreements on sanitary and phytosanitary standards (Ministerio de Comercio, Industria y Turismo, 2013; Direcon, 2013; Mincetur, 2013; Secretaría de Economía, 2013; Comunidad Andina, 2006b). 
Table 3

Current situation for tariff concessions

for goods between Pacific Alliance members

\begin{tabular}{l|l|l|l|l}
\hline & Colombia & Chile & Peru & Mexico \\
\hline Colombia & - & $99 \%$ (FTA) & $100 \%$ (CAN) & $92 \%$ (FTA) \\
\hline Chile & $99 \%$ (FTA) & - & $\begin{array}{l}93 \% \text { (Economic } \\
\text { Commercial Agreement) }\end{array}$ & $99 \%$ (FTA) \\
\hline Peru & $\begin{array}{l}100 \% \\
\text { (CAN) }\end{array}$ & $\begin{array}{l}93 \% \text { (Economic } \\
\text { Commercial Agreement) }\end{array}$ & - & $85 \%$ (FTA) \\
\hline Mexico & $92 \%$ (FTA) & $99 \%$ (FTA) & $83 \%$ (FTA) & - \\
\hline
\end{tabular}

Data source: Ministerio de Comercio, Industria y Turismo, 2013; Direcon, 2013; Mincetur, 2013; Secretaría de Economía, 2013.

However, each member country has internal admission criteria for imports, and its own regulatory bodies, which represent a non-tariff barrier (NTB) since the differences involve additional costs and time-consuming approval processes that limit intra-regional trade. The Paranal Presidential Declaration - signed on June 6th 2012 which gave birth to the PA-, set a roadmap with concrete actions to unify procedures. Since the negotiations in the PA are founded on pre-existing agreements, it is important that added-value aspects are aligned with admissions criteria set specifically for agricultural, livestock and food products (Declaración de Paranal, 2012).

Likewise, certificates of origin have been an element of all negotiated agreements previous to the emergence of the PA. Each agreement has set different rules of origin including both severe and flexible clauses, which allow clear access conditions (Comunidad Andina, 2006b).

Regarding accumulation of rules of origin, these have been a key market access rule in preferential trade agreements, and critical gatekeepers for trade (Estevadeordal, Suominen, Sanguinetti \& Trejos, 2005). It has been demonstrated that the rules of accumulation of origin which Colombia has in agreements such as the ones with the United States and with European countries, has increased the potential for market expansion due to the incentives given to developing transnational production chains, which leverage the competitive advantages of each country, and of regions within the country (Comunidad Andina, 2006b).

For instance, as it was documented by the Colombian exports promotion agency (Proexport, 2013), Colombia exported USD 24,475 in pineapples to 
Chile in 2012, with 0\% tariffs due the existing FTA between the two countries. In turn, Chile imported pineapples for USD 13.8 million from different countries to transform it into pineapple juice, of which it exported a total of USD 59.7 million worldwide. From this figure, USD 665,000 went to China. China in turn, imported a total of USD 13 million of pineapple juice in the same year. Therefore, based on this example, it appears that there is an opportunity to take advantage of tariff reductions to generate productive chains to respond to the needs of third markets.

On the other hand, countries participating in the the PA have boosted their international trade based on services. In 2011, the four countries imported an aggregate USD 542,6 million in services while exporting USD 535,9 million to various countries (UNCTADstat, 2013). It is clear that the balance between exports and imports of services in the Alliance shows a deficit which can be attributed to imports of transport services. In 2011 alone it accounted for $43 \%$ of total imports of services (International Trade Center, 2013). However the total trade in services increased by $28 \%$ compared to the traded amount in 2009 in the same category (International Trade Center, 2013; UNCTAD, 2013; UNCTADstat, 2013).

Figure 1

Evolution of exports of services of the members of the Pacific Alliance in the period 2000-2012

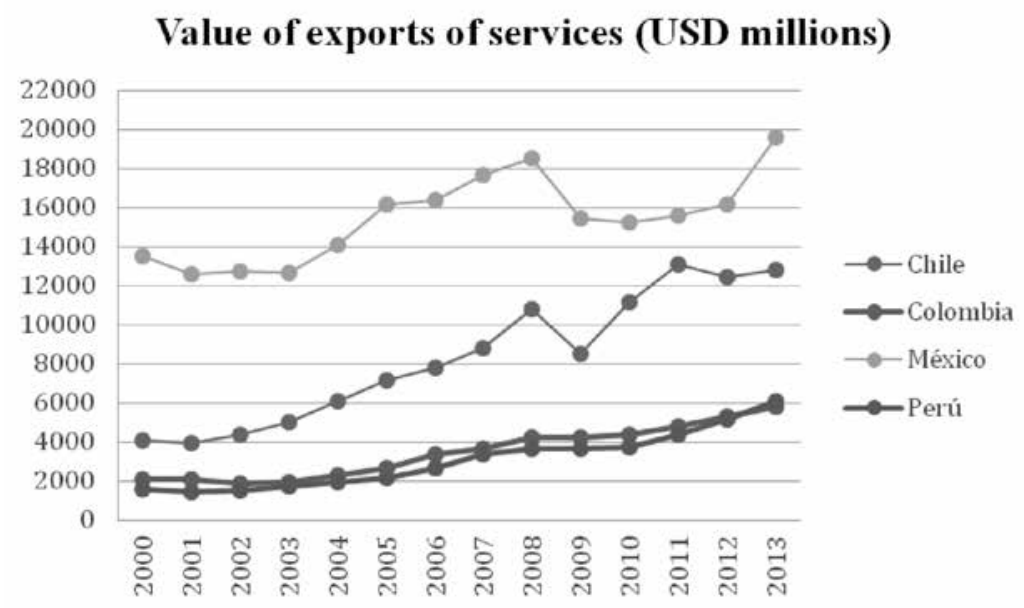

Data source: UNCTAD Handbook of Statistics/UnCTADstat (2002, 2007, 2009, 2010, 2014). 
Mexico is listed as the largest exporter of services in the PA. However, despite the fact that Mexico has a developed tourism sector boosting the export of services, it is still below potential. This would be explained by the concentration of economic activities, policies and public budgets on manufacturing rather than services (Giuliani, Pietrobelli \& Rabellotti, 2005; López \& Torre, 2009; Micheli, 2012; UNCTAD, 2013).

The growth of international trade of services such as health, advertising, research and development, and business analytics has been evident for both the private and the public sector. Also, the emergence of knowledge-based industries has increased the level of exports in the world, and in Latin America countries (UNCTAD, 2013). These industries have been closely linked with the global fragmentation of production which has led to global value chains (GVC) (Gereffi \& Sturgeon, 2005, Gereffi, 2013; Lopez et al., 2009). Participating in GVCs has set export opportunities for services to international markets, especially to developed nations. According to different authors (López et al, 2009; Gereffi et al, 2005; Giuliani et al., 2005) Latin American countries can be integrated into different segments of the GVC in services, allowing them to generate jobs and attract FDI.

Mexico has experience working in clusters and participating in GVC in the services sector, which has led to accumulation of knowledge and increased competitiveness. It has been documented that industries that participate in GVCs tend to grow faster as they adopt international standards on the basis of inter-firm cooperation (Giuliani, et al., 2005; Micheli, 2012). Working together in clusters like in Mexico, especially in the service sector, has led to a more effective use of opportunities (idem). Since one of the goals of the PA is to facilitate trade of services by unifying regulations and undertaking a joint trade promotion, integrating production processes in GVC can accelerate sectorial growth and increase commercial interaction.

\subsection{Political powers in Latin America}

As it has been mentioned above, the Pacific Alliance represents the latest development in the landscape of integration processes in Latin America. The integrationist movement which began in the 1960s under the aegis of the United Nations Economic Commission for Latin America and the Caribbean (ECLAC), went through a wave of liberalization in the 1990s. Nevertheless, after the failure of the Us-led Free Trade Area of the Americas (FTAA) which 
stagnated in 2005, the last decade has been dominated by an inward-looking regional focus where Latin American economies joined efforts as a way to counter the influence of extra-regional powers.

The Pacific Alliance marks the return of the "open regionalism" approach that had gained momentum in the region during the 1990s. Broadly defined, "open regionalism" stands for an outward-oriented and internationally competitive-seeking approach, implying the free movement of goods, services, labour and capital, as well as policy and regulatory coordination in a fashion that is inclusive both for the acceptance of new members willing to abide by these principles, and for the association with extra-regional partners (Kuwayama, 1999; ECLAC, 1994).

In that respect, the PA explicitly distances itself from other regional initiatives, and particularly from Mercosur which is the most advanced initiative so far, in which integration with extra-regional partners has been either neglected or openly rejected. However, the PA includes as well the prioritizing of a regional objective, namely the Asia Pacific region. Within the complex of integration agreements that exists in Latin America, the Pacific Alliance comes as a response from four countries to promote open regionalism, seeking to advance the process of economic integration among them as well as their global outreach, overcoming the ideological divergence found within other regional groups.

One of these contrasting cases is Unasur. The cooperation areas identified by the PA and Unasur are similar. However, the PA notably differs in its explicit outward-looking purpose. On the other hand, in Unasur, members have different visions regarding economic liberalization and the structure of the international financial system. An illustrative example is the creation of the Bank of the South which has been established by Unasur as an alternative to the IMF and the World Bank; it is not by coincidence that Colombia, Chile and Peru (members of Unasur and the PA) were the only Unasur members that abstained from fully joining this bank.

Another illustrative case is the Andean Community of Nations (ACN). After the withdrawal of Venezuela in 2006, the ACN has been polarized between the members who advocate for outward liberalization (Peru and Colombia) and the members who opposed the signature of deals with extra-regional partners (Casas \& Correa, 2007). The Pacific Alliance thus constitutes a framework for Peru and Colombia to advance their integration and their projection for integrating with partners beyond the Andean area. 
The emergence of the Pacific Alliance also signifies a potential reordering of relative political weight in Latin America. During the last decade, Brazil has sought to become both a regional power and a prominent global player (Malamud, 2011). At the regional level, Brazil was active in promoting ACNErcosur rapprochement and the further promotion of South American unity through the Union of South American Nations (Unasur, by its Spanish and Portuguese acronym). On the other hand, Mexico, which is the other Latin American big power in terms of both economy and population, had been rather distanced from regional affairs as it deepened its integration with the US (its main partner in NAFTA) and struggled to tame its inner drug wars.

Mexico began to catch up with Latin American affairs when it promoted the upgrading of the so called Group of Rio into the Community of Latin American and Caribbean States (CELAC, by its acronym in Spanish), a rather consultative organization that brings together all the western hemisphere states except the US and Canada (SRE Mexico, 2010).

Mexico's inclusion in the Pacific Alliance represents its formal comeback into the dynamics of economic integration in Latin America. It also represents a shift of mind-set regarding its possible integration with Asia. Traditionally, Mexico had kept distance from Asian partners apart from Japan, as it regarded developing nations in that continent (particularly China) as rivals for a stake in the U. S. manufactured goods market (Hernández, 2012). Besides entering the PA, Mexico is also participating in the negotiations to establish the Trans Pacific Strategic Economic Partnership (TPP) (Schiavon \& Velásquez Flores, 2012).

\subsection{Diplomatic dimensions}

The Pacific Alliance differs and stands out from other integration initiatives in the continent in the implementation of shared projects of the representation of its members abroad. The first of these projects is an embassy in Ghana, inaugurated by Colombia and later shared with Chile, Peru and Mexico. Colombia and Chile also signed agreements to share the latter's embassy buildings in Morocco and Algeria. Peru and Colombia will share physical space in Vietnam, as well as Mexico and Colombia expressed their intention to do the same with the offices that Mexico currently has in Singapore.

Even though it is common to make reference to these as "shared" or "joint" embassies, these are in fact different diplomatic representations that 
only share a physical space. This is different from, for example, the European Union's Delegations where there is a common representation and a single representative (i.e. one embassy, one ambassador).

The biggest beneficiary of the shared embassies scheme is Colombia. Before the establishment of the PA, Colombia had just 14 Diplomatic Missions in Asia, Africa and Oceania, in comparison to Chile's 23, Peru's 19 and Mexico's 26. In Colombia, maintaining diplomatic representations abroad has been somewhat regarded as a hindrance to the national finances. In fact, the previous administrations closed embassies in countries that were not regarded as priority (mainly in Asia, Africa and Oceania) with the argument that they were not economically sustainable (Galan, 2007).

\section{Table 4}

PA Members' diplomatic representation in Asia, Africa and Oceania

\begin{tabular}{l|l|l}
\hline & Diplomatic Missions Abroad & Diplomatic Missions Abroad \\
\hline Chile & Algeria, Egypt, Kenya, Morocco, & Algeria, Egypt, Kenya, Morocco, \\
& South Africa, United Arab Emirates, & South Africa, United Arab Emirates, \\
& Israel, Jordan, Lebanon, Syria, Turkey, & Israel, Jordan, Lebanon, Syria, Turkey, \\
& China, South Korea, Philippines, & China, South Korea, Philippines, \\
& India, Indonesia, Japan, Malaysia, & India, Indonesia, Japan, Malaysia, \\
& Singapore, Thailand, Vietnam, & Singapore, Thailand, Vietnam, \\
& Australia, New Zealand. & Australia, New Zealand. \\
& Opened after the PA: & Opened after the PA: \\
& Ghana. & Ghana. \\
\hline Colombia & Egypt, Kenya, South Africa, United & Egypt, Kenya, South Africa, United \\
& Arab Emirates, Israel, Lebanon, & Arab Emirates, Israel, Lebanon, \\
& Turkey, China, South Korea, India, & Turkey, China, South Korea, India, \\
& Indonesia, Japan, Malaysia, Australia. & Indonesia, Japan, Malaysia, Australia. \\
& Opened after the PA: & Opened after the PA: \\
& Thailand, Ghana (shared PA embassy), & Thailand, Ghana (shared PA embassy), \\
& Algeria (announced to be shared with & Algeria (announced to be shared with \\
& Chile), Morocco (shared with Chile), & Chile), Morocco (shared with Chile), \\
& Vietnam (announced to be shared & Vietnam (announced to be shared \\
& with Peru). & with Peru). \\
\hline
\end{tabular}




\begin{tabular}{l|l|l}
\hline & Diplomatic Missions Abroad & Diplomatic Missions Abroad \\
\hline Mexico & Algeria, Egypt, Ethiopia, Kenya, & Algeria, Egypt, Ethiopia, Kenya, \\
& Morocco, Nigeria, South Africa, Saudi & Morocco, Nigeria, South Africa, Saudi \\
& Arabia, United Arab Emirates, Iran, & Arabia, United Arab Emirates, Iran, \\
& Israel, Kuwait, Lebanon, Turkey, & Israel, Kuwait, Lebanon, Turkey, \\
& China, South Korea, Philippines, & China, South Korea, Philippines, \\
& India, Indonesia, Japan, Malaysia, & India, Indonesia, Japan, Malaysia, \\
& Singapore, Thailand, Vietnam, & Singapore, Thailand, Vietnam, \\
& Australia, New Zealand. & Australia, New Zealand. \\
& After the PA: & After the PA: \\
& Ghana. & Ghana. \\
\hline \multirow{2}{*}{ Peru } & Algeria, Egypt, Morocco, South Africa, & Algeria, Egypt, Morocco, South Africa, \\
& Saudi Arabia, United Arab Emirates, & Saudi Arabia, United Arab Emirates, \\
& Qatar, Israel, Kuwait, Turkey, China, & Qatar, Israel, Kuwait, Turkey, China, \\
& South Korea, India, Indonesia, & South Korea, India, Indonesia, \\
& Japan, Malaysia, Singapore, Thailand, & Japan, Malaysia, Singapore, Thailand, \\
& Australia. & Australia. \\
& After the PA: & After the PA: \\
& Ghana, Vietnam (to be shared with & Ghana, Vietnam (to be shared with \\
& Colombia). & Colombia). \\
\hline
\end{tabular}

Note: Chile and Mexico have representation offices before the Palestinian National Authority; also, Chile, Mexico and Peru have commercial offices in Taiwan that deal with bilateral affairs. However, none of these representations constitute a formal diplomatic mission.

The "shared embassies" scheme allows PA members to divide among themselves the economic burden of maintaining or establishing a permanent representation abroad and makes it easier for the member states to justify their existence before national constituencies.

As far as commercial representation offices, the four countries of the Pacific Alliance have established a joint office in Istanbul and have plans to open new ones in New Delhi, Sydney, Casablanca, among others.

Another area of potential cooperation area is open in consular services. The citizens of a PA Member could apply for consular services or request emergency assistance at another member's consular office in a country.

\section{Private Sector Strategies}

The PA represents an opportunity for companies from member countries to establish partnerships that allow them to complement their global supply 
and to broaden their markets, especially regarding their potential access to Asian markets.

The last 20 years have seen the emergence and strengthening of multinational companies based in Latin America. The region wide economic liberalization that occurred during the 1990s propelled the internationalization of local companies given the inflow and availability of foreign exchange derived from trade and investment, and also because of the increased competition from foreign companies within their markets (Cuervo-Cazurra, 2008; GonzálezPérez \& Vélez-Ocampo, 2014; Santiso, 2008, 2013).

According to Latin Trade's 2013 ranking of multilatinas, the AP countries account for 34 of the 100 largest multinationals in Latin America by revenues: 10 in Chile, 22 in Mexico, and 2 in Colombia. These companies are in retail (9), energy (7), mining (5), telecommunications (4), food and beverages (4), holding companies (3), and cement (1).

As shown in a report of the Inter-American Development Bank (IADB) (Casanova \& Fraser, 2009), the main driver for the expansion of Latin American multinational companies from the consumer goods and services sectors beyond their national boundaries is the need or their desire to expand their markets, as their local market gets saturated. So far, the most successful cases of Latin American companies expanding beyond the region are the ones belonging to extractive and heavy industries, which happen to be mainly Brazilian companies (and to a lesser degree, Mexican and Chilean companies) that have seen and increased demand for commodities and primary products from rapidly developing Asian economies.

The IADB report identifies three advantages that must be developed by Latin American multinationals in order to expand intra and extra-regionally. These are innovation, differentiation and segmentation, and leadership from local entrepreneurs. As the PA seeks to establish itself as a platform for integration with extra-regional partners, especially in Asia-Pacific, it must develop joint efforts to foster the development of these advantages by its member countries' companies, especially for those that do not belong to the extractive sector.

In the intra-regional context of the PA, it is worth noting the dynamic relation between Chile, Peru and Colombia in terms of foreign direct investment. Chilean companies have entered the Colombian market, first in electric energy and later expanding into finance and retail services. In 2012 Chile was positioned as the largest source of FDI in Colombia with US $\$ 3,074$ million, 
which is equivalent to $54 \%$ of the total non-oil investment in Colombia that year (Banco de la República, 2013).

Peruvian companies are also advancing their insertion into PA markets in economic sectors such as construction, agribusiness and finance, especially in Colombia where there is a growing presence of companies dedicated to finances, and commercializing of food and beverages and cosmetics. On the other hand, Colombian companies have been investing in infrastructure projects in Chile and expanding in financial services in Peru.

On the side of Mexican companies, it is worth mentioning the strong presence of cement and bakery business in Colombia as well as the expansion of telecom services throughout the region. However, FDI with Mexico does not have the "double way" nature, present among the other three PA members.

An element which could strengthen investment among the PA countries and potentially foster alliances among their companies is the consolidation of the Integrated Latin American Market (MILA, by its Spanish acronym), which currently brings together the stock markets of Chile, Colombia and Peru. Mexico is expected to join during 2013.

The union of the stock markets has several appealing features. On the side of the issuers, MILA offers a deeper more liquid market, and on the side of the investors, it allows them to find better risk and yield options among the associated markets (Oxford Analytica, 2010). Mila also diversifies the overall composition of the regional markets as each national marketplace has singular features. In Chile, the retailers have a strong position, whereas in Colombia the oil sector is dominant. In Peru the mining companies lead the local market.

The PA is also an opportunity to articulate production chains, taking advantage of each country's productive advantages. As shown above in the example of the business between Colombia and Chile for the production and export of pineapple juice to Asia, the PA countries can take advantage of tariff elimination and trade facilitation among them in order to articulate production chains that enable them to competitively supply an extra-regional market.

The national agencies for the promotion of trade and investment have been active in promoting these cross-country business initiatives, through advisory services to companies and through events that promote the interaction between businesspeople of the region. In February 2012, the four national agencies - Proexport Colombia, Promperu, Prochile and Promexico, established a joint strategy to coordinate their presence on international 
fairs, exchange experiences, jointly provide consulting services to businesses and to lay out a common strategy to enter new markets, especially in Asia (Proexport, 2012.) In June 2013, they held the first Business Round of the Pacific Alliance in Cali, Colombia, where businesses worth USD 4 million were made (Mayoralty of Cali, 2013).

From a political perspective, the efforts and achievements that have materialized so far could be complemented by a joint policy that helps identify and promote strategic industries which can be articulated in competitive PA production chains. In this sense it is key to bring together the inputs from the promotion agencies as well as from the Entrepreneurial Council of the $\mathrm{PA}$, where prominent businessmen from the region are represented.

\section{Implications for regional and extra-regional trade}

Besides adding political backing to the economic integration processes among member countries, the PA could boost trade and investment with regional and extra-regional partners.

For instance, countries which want to be full members of the Alliance are required to have free trade agreements with all of the PA members. This requirement has induced the signing of new bilateral trade agreements (FTA).

A Colombia-Costa Rica FTA was negotiated in just four rounds and two ministerial meetings between June 2012 and February 2013, and was signed in May 2013 in Cali, Colombia, during the VII Summit of the Pacific Alliance. Also, in March 2013, Colombia and Panama reopened the negotiations of their FTA which started in March 2010, and had been stalled since its fifth round in October 2010. On September 20, 2013, the Colombia-Panama FTA was signed.

In terms of extra-regional trade liberalization, thus far PA members' negotiations with Asia-Pacific have been approached in a bilateral fashion. Peru is the member with more Free Trade Agreements with Asian counterparts, with five FTAs, followed by Chile with 4 (see Table 5 below.) Mexico has only established Free Trade relations with Japan. As it was noted, Japan took the initiative as it tried to avoid a disadvantageous position for Japanese companies in Mexico after NAFTA (Villarreal, 2012.) Colombia is a latecomer to the process, having signed just an FTA with South Korea in 2013, and currently negotiating an agreement with Japan. 
Table 5

PA members' FTAs with Asia-Pacific economies

\begin{tabular}{l|l|l|l|l}
\hline & Chile & Colombia & Mexico & Peru \\
\hline Australia & In force (2009) & & & \\
\hline China & In force (2006) & & & In force (2010) \\
\hline Japan & In force (2007) & Negotiating & In force (2005) & In force (2012) \\
\hline South Korea & In force (2004) & Signed (2013) & & In force (2011) \\
\hline Singapore & & & & In force (2009) \\
\hline Thailand & & & & In force (2011) \\
\hline TPP & Negotiating & & Negotiating & Negotiating \\
\hline
\end{tabular}

Source: based on Garcia (2013: 349) and adapted by the authors with information take from SICE-OAS (2013).

Taking into account that three of the four PA members are negotiating their entry to the Trans Pacific Strategic Economic Partnership (TPP), this is the first and farthest-reaching opportunity for the PA to act as a block on trade negotiations with Asia-Pacific. However, some challenges must be overcome.

The first challenge is the lack of a common negotiating position among the three PA members that participate in TPP negotiations. Each country has different views regarding strategic sectors to be protected or liberalized. As mentioned already, Mexico has been wary of the impact that a commercial agreement with Asian economies could have on its manufacturing sector, and it is also worth noting that during its recent negotiation of an FTA with Peru it sought to protect its agricultural sector (Morales, 2011). In contrast, Chile - along with Australia, New Zealand and Singapore- has offered to fully eliminate tariffs on agricultural and industrial goods (Japan Times, 2011).

The second challenge is the fact that Colombia is not participating in the TPP negotiations, as it has not been able to get a full membership to the Asia-Pacific Economic Forum (APEC), despite its persistent attempts to join since 1995 due to a sustained moratorium on new members (Roldán Pérez, 2010). Even though membership in APEC is not a formal requisite to join the TPP, the countries which are now negotiating have been reluctant to accept APEC outsiders (Meacham, 2013). Chile, Mexico and Peru, as APEC members and TPP negotiating countries, should establish a common position to support and make effective the entry of Colombia. 
The same situation applies to Costa Rica and Panama, which are in the process of becoming full PA member states. Both countries have also unsuccessfully attempted to join APEC during recent years, and this could hinder their chances to join the Trans Pacific initiative.

\section{Future of the Pacific Alliance}

The Pacific Alliance is designed to serve as the platform for integration with Asia. However, it is important to question what the real potential of this promise is, and how significant is the trade block in the international arena as a commercial platform.

Diana Pita, ${ }^{5}$ Economic and Commercial Counsellor of Peru to Beijing, interviewed by the authors in May 2013, said the PA has a great trade potential. For instance, she states that China has displayed a clear interest in the block, acquiring observer status and seeking ways to establish a mechanism for trade and economic dialogue with the PA. On the other hand, Sebastian Herreros, ${ }^{6}$ Economic Affairs Officer, Division of International Trade and Integration of the Economic Commission for Latin America and the Caribbean (ECLAC), also interviewed by the authors on May 2013, noted that, even though the PA countries want to establish a strong business relationships with Asia, the PA has not been until now the platform that is being used to achieve this. "All these countries have pursued a bilateral or multilateral connection with Asia, through another vehicle: the Transpacific Initiative," he says. "In this context, the truth is that today I do not see the Alliance as a being yet a relevant tool for the negotiation of agreements with Asia; clearly, PA members are favouring other ways of negotiation."

As for trade possibilities, one must ask if the Alliance is attractive to Asian countries. In the case of Chile and Peru it is clear that trade with Asia is seen as a great opportunity, since these are foodstuff producers, which are in good demand. The case of Mexico, however, is more complex, since having a stronger industrial base, it can be seen more as a competitor than as an opportunity.

5. Pita, Diana. Economic and Commercial Counselor of Peru to Beijing. Interviewed on May 2013.

6. Herrerros, Sebastian. Economic Affairs Officer, Division of International Trade and Integration of the Economic Commission for Latin America and the Caribbean (ECLAC). Interviewed on May 2013. 
In this regard, Diana Pita suggests that "what we have in common is the food sector. We can excel as suppliers for China. Our main strength lies in promoting the region as an able and reliable food provider." In this case, we would have to wait and see how the block sells itself: will the PA countries unify their efforts to become Asia's pantry, leaving aside the opportunities to exploit and develop the industrial sector? Herreros noted that Colombia, with a relatively strong industry, for example in the textile field, could benefit more if it moves toward the food sector. Mexico, in turn, with a much stronger industry, would have to ponder if they should move at all in the direction of what appears to be a clear bet on the foodstuff sector.

\subsection{Potential market access and balance of powers in Latin America}

Due its pragmatic view for advancing towards a rapid integration on several fronts, the Pacific Alliance could potentially replace Mercosur as the largest and most effective trading bloc in Latin America.

In 2013 member countries decided to systematically remove their tariff barriers, and defined a timeline for the gradual implementation of this decision. They negotiated tax and investment agreements, designed a single foreign trade platform, and devised unified mechanisms to control massive inflows of foreign capital. They also have made it their common goal to obtain a better trade and diplomatic treatment in Asia. This pragmatic approach reduced the scepticism that was built around the previous regional integration attempts in Latin America.

Mexico could have an additional benefit from being a member, as the AP could move the axis of Latin American integration away from Brazil, north to Mexico.

This pragmatic stance has created a genuine interest in participating in neighbouring countries. Costa Rica, Panama and Guatemala, have already moved forward in the process and gained observer status. It has also generated an interest in Canada. An interview made by the authors with the U. S. assistant secretary of state for Western Hemisphere affairs, Roberta S. Jacobson, ${ }^{7}$ showed that, at least publicly, the alliance has not produced a large amount of enthusiasm in the United States. However the status of this

7. Jacobson, Roberta S. Assistant Secretary of State for Western Hemisphere Affairs. Interviewed on June 2013. 
country as an observer in the PA, plus the fact that all the PA members have FTAs with it, offer a chance for enhanced cooperation.

Based on other regional integration agreements, it seems clear that the current momentum of the PA will only be maintained if there is a permanent political support to the process, since there are no evidences that key economic variables, such as interest rates and inflation, or legal or social structures would organically improve when implementing a trade pact. Nonetheless, compatible criteria of member states regarding the treatment of FDI, foreign trade, and the desire to contest the economic and political power of dominant Brazil, suggests that the Pacific Alliance will have the support of the allied governments, at least in the near future.

\section{Final remarks: Conclusions}

The Pacific Alliance countries, from an economic perspective, embrace the principles of liberalization, as well as they apply economic policies aimed to keep a low rate of inflation and to promote private sector initiative as the motor of their economies. In the political side, these countries have strong relations with the United States. Mexico, which is at the same time the second largest economy and the second most populated nation in Latin America, was the regional pioneer in subscribing a Free Trade Agreement with the United States and also has similar treaties with countries outside of the American continent.

The formation of the Pacific Alliance, which is the first multilateral Free Trade project in the continent after the failure of the FTAA, can be seen as a move to counteract the expansion of the integration initiatives led by the region's leftist group of countries (Brazil, Venezuela, and Argentina) during the last decade. Besides promoting Free Trade and integration with extra-regional partners, the Pacific Alliance countries have also boycotted initiatives such as the creation of the Bank of the South, the South American alternative to the International Monetary Fund promoted by the Mercosur countries.

From the constructivist perspective, the process of integration between these four countries is not a sudden development, because it has been gradually taken place during the last two decades. Before establishing the Pacific Alliance, all four member states already had bilateral Free Trade Agreement between them, so this late initiative is nothing but the consolidation and unification of the integration process that encompasses a set of like-minded countries seeking to advance both their economic and political integration. 


\section{References}

Ardila, M. (2012), El Pacífico latinoamericano y su inserción internacional, Bogota: Editorial Pontificia Universidad Javeriana.

Baier, S. L. \& Bergstrand, J. H. (2007), "Do free trade agreements actually increase members' international trade?", Journal of International Economics, No. 71, pp. 72-95.

Baker, A. \& Greene, K. (2011), "The Latin American Left's Mandate: Free-Market Policies and Issue Voting in New Democracies", World Politics, 66(1): 43-77.

Baldwin, R. \& Jaimovich, D. (2012), "Are Free Trade Agreements contagious?", Journal of International Economics, 88(1): 1-16.

Banco de la República (2013), Foreign Direct Investment in Colombia - Colombian Central Bank Statistics. Available online at http://www.banrep.gov. co/sites/default/files/paginas/C2Flujo_Paises_2007.xls, last accessed 25 September 2013.

Bhagwati, J. (2008), Termites in the Trading System: How Preferential Agreements Undermine Free Trade, Oxford: Oxford University Press.

Briceño Ruiz, J. (2012), "La alianza del Pacífico: La viabilidad de un naciente bloque regional”, in Ardila, M. (ed.), El Pacífico latinoamericano y su inserción internacional, Bogota: Editorial Pontificia Universidad Javeriana, pp. 135-157.

Bulmer-Thomas, V. (1998), "The Central American common market: From closed to open regionalism", World Development, 66(1): 313-322.

Busch, M. L. \& Reinhardt, E. (2003), "Developing Countries and General Agreement on Tariffs and Trade/World Trade Organization Dispute Settlement", Journal of World Trade, 37(4): 719-735.

Casanova, L., Fraser, M. et al. (2009), Multilatinas to Global Latinas: The New Latin American Multinationals, Washington, DC: Inter-American Development Bank.

Casas, A. \& Correa, M. E. (2007), “¿Qué pasa con la Comunidad Andina de Naciones - CAN? / What is wrong with the Andean Community?", Papel Político, 12(2): 591-632.

Celli, U., Salles, M., Tussie, D. \& Peixoto, J. (2010), Mercosur in South-South Agreements: In the middle of two models of regionalism, Geneva: UNCTAD Virtual Institute-Knowledge Sharing, Training and Capacity Development Branch-Division on Technology and Logistics. 
Colleman, W. D. \& Underhill, G. (1998), Regionalism and Global Economic Integration: Europe, Asia and the Americas, New York: Routledge.

Comunidad Andina (2006a), Convergencia comercial de los países de América del Sur hacia la comunidad sudamericana de naciones. Aranceles y comercio en sudamericana: Análisis de la convergencia hacia el libre Comercio. Available online at: http://www.comunidadandina.org/unasur/Convergencia2-\%20 Aranceles\%20y\%20comercio.pdf, last accessed 25 September 2013.

(2006b), Convergencia comercial de los países de América del Sur hacia la comunidad sudamericana de naciones. Normas de Origen (ACES 58 y 59 y Decisión 416 de la CAN). Available online at: http://www.comunidadandina.org/unasur/Convergencia3-\%20Normas\%20de\%20origen.pdf, last accessed 25 September 2013.

Cuervo-Cazurra, A. (2008), "The multinationalization of developing country MNEs: The case of Multilatinas", Journal of International Management, 14(2): 138-154.

Dade, C. \& Meacham, C. (2013), The Pacific Alliance: An example of lessons learned, Washington, DC: Centre for Strategic and International Studies - csis. Available online at: https://csis.org/files/publication/130711_ CDadeCMeacham_PacificAlliance.pdf, last accessed 25 September 2013. Darnton, C. (2012), "A false start on the road to Mercosur: Reinterpreting rapprochement failure between Argentina and Brazil", Latin American Research Review, 47(2): 120-143.

Declaración de Lima (2011), Declaration of the I Summit of the Pacific Alliance - Lima, Peru. Available online at: http://alianzapacifico.net/documents/ AP_Declaracion_Lima_I_Cumbre.pdf, last accessed 25 September 2013. Declaración de Paranal (2012), Declaration of the IV Summit of the Pacific Alliance - Antofagasta, Chile. Available online at: http://www.minrel.gob.cl/ prontus_minrel/site/artic/20120606/asocfile/20120606160551/declaracion_de_paranal_06_06_2012_1.pdf, last accessed 25 September 2013.

Devlin, R. \& French-Davis, R. (2002), "Towards an Evaluation of Regional Integration in Latin America in the 1990s", The World Economy, 22(2): 261-290.

Direcon (2013), Trade Agreements in force. Ministry of Foreign Affairs of Chile (2013). Available online at: http://www.direcon.cl/, last accessed 25 September 2013.

ECLAC (1994), Open Regionalism in Latin America and the Caribbean: Economic integration as a contribution to changing production patterns with social 
equity, Santiago de Chile: Economic Commission for Latin America and the Caribbean.

Estevadeordal, A., Suominen, K., Sanguinetti, P. \& Trejos, A. (2005), "Rules of Origin in Preferential Trading Arrangements: Is All Well with the Spaghetti Bowl in the Americas?", Economía, 5(2): 63-103.

François, J. F., McQueen, M. \& Wignaraja, G. (2005), "European Union - Developing country FTAs: Overview and analysis”, World Development, No. 33, pp. 1545-1565.

Galan, J. M. (2007), "Evaluation of Colombian Foreign Policy - A view from the Colombian Senate", Colombia Internacional, No. 65, pp. 164-178.

García, M. (2013), "Resources and Trade: Linking the Pacific through Bilateral Free Trade Agreements (FTA)”, Journal of World Trade, 47(2): 329-358.

Garman, G. \& Gilliard, D. (1998), "Economic Integration in the Americas: 1975-1992", The Journal of Applied Business Research, 14(3): 1-13.

Gereffi, G. (2013), "Global value chains in a post-Washington Consensus Worlds", Review of International Political Economy, Routledge, pp. 1-29.

Gereffi, G., Humphrey, J. \& Sturgeon, T. (2005), “The governance of global value chains", Review of International Political Economy, 12(1): 78-104.

Giuliani, E., Pietrobelli, C. \& Rabellotti, R. (2005), "Upgrading in global value chains: Lessons from Latin American clusters", World Development, 33(4): 549-573.

González, A. (2009), "Revitalizing the us Trade Agenda in Latin America: Building on the FTA Platform", Journal of International Economic Law, No. 12, pp. 539-546.

González-Pérez, M. A. \& Vélez-Ocampo, J. F. (In press), “Targeting one’s own region: Internationalisation trends of Colombian multinational companies", European Business Review.

Haas, E. (1965), The politics of economics in Latin American regionalism: The Latin American Free Trade Association after four years of operation, Denver: Social Science Foundation/Graduate School of International Studies-University of Denver.

Hernández, R. (2012), "Economic Liberalization and Trade Relations between Mexico and China", Journal of Current Chinese Affairs, 41(1): 49-96.

Hojman, D. E. (1981), "The Andean Pact: Failure of a Model of Economic Integration?", Journal of Common Markets Studies, 20(2): 139-160.

International Trade Center (2013), Trademap: Trade statistics for international business development. Available online at: http://www.trademap.org 
Japan Times (2013), "Four TPP Members offer to kill all Tariffs", The Japan Times - News (21 September, 2013). Available online at: http://www. japantimes.co.jp/news/2013/09/21/national/four-tpp-members-offerto-kill-all-tariffs/\#.UkSfpoZWySo, last accessed 25 September 2013.

Jessop, B. (2013), "Dynamics of regionalism and globalism: a critical political economy perspective", Journal of Ritsumeikan Social Science and Humanities, No. 5, pp. 3-24.

Krapohl, S. \& Fink, S. (2013), "Different Paths of Regional Integration: Trade Networks and Regional Institution-Building in Europe, Southeast Asia and Southern Africa", JCMS: Journal of Common Market Studies, 51(3): 472-488.

Kuwayama, M. (1999), Open Regionalism in Asia Pacific and Latin America: A survey of the literature, Santiago de Chile: Economic Commission for Latin America and the Caribbean-International Trade and Development Finance Division.

López, A., Ramos, D. \& Torre, I. (2009), Las exportaciones de servicios de América Latina y su integración en las cadenas globales de valor. Documento presentado a la Oficina de la Secretaría Ejecutiva de la CEPAL, Santiago de Chile: Economic Commission for Latin America and the Caribbean. Available online at: www.eclac.org/publicaciones/xml/3/35963/DocW37fin.pdf, last accessed 25 September 2013.

López, D. \& Muñoz, F. (2012), "El inicio formal de la Alianza del Pacífico", Puentes - ICTSD, No. 12, pp. 18-23.

Malamud, A. (2005), "Mercosur Turns 15: Between rising rhetoric and declining achievement", Cambridge Review of International Affairs, 18(3): 421-436.

- - (2011), "A Leader without Followers? The Growing Divergence between the Regional and Global Performance of Brazilian Foreign Policy", Latin American Politics and Society, 53(3): 1-24.

Malamud, C. (2013), "La Alianza del Pacífico: Un revulsivo para la integración regional en América Latina", Real Instituto Elcano. Available online at: http://www.iadb.org/intal/intalcdi/PE/2012/10980.pdf, last accessed 25 September 2013.

Mayoralty of Cali (2013), Macrorrueda de Negocios de la Alianza del Pacífico permitió cerrar millonarios negocios. Available online at: http://www.cali. gov.co/redbibliotecas/publicaciones.php?id=52160, last accessed 25 September 2013. 
Meacham, C. (2013), "Why Colombia is not in the Trans-Pacific Partnership?", Center for Strategic and International Studies - CSIS (2 July, 2013). Available online at: http://csis.org/publication/should-colombia-join-trans-pacific-partnership, last accessed 25 September 2013.

Mecham, M. (2003), "Mercosur: a failing development project”, International Affairs, 79(2): 369-385.

Micheli, J. (2012), "El sector de call centers: Estructura y tendencias. Apuntes sobre la situación de México", Frontera Norte, 24(47): 145-169.

Milenky, E. S. (1973), The politics of regional organization in Latin America: The Latin American Free Trade Association, New York: Praeger.

Mincetur (2013), International Tourism Statistics, Ministry of Foreign Trade and Tourism of Peru. Available online at:http://www.mincetur.gob.pe/ turismo/estadistica/Diario/con_migracion.asp, last accessed 25 September 2013.

Ministerio de Comercio, Industria y Turismo de Colombia (2013), Trade and Investment Agreements of Colombia, Ministry of Trade, Industry and Tourism. Available online at: http://www.tlc.gov.co/, last accessed 25 September 2013.

Mols, M. (2005), "APEC and Latin America: Completing the Pacific Rim agenda”, in Rüland, J., Manske, E., \& Draguhn, W. (eds.), Asia-Pacific Economic Cooperation (APEC): The First Decade, New York: Routledge, pp. 72-86.

Morales, R. (2013), "Acuerdan México y Perú TLC con apertura total en 10 años”, El Economista (6 April 2011). Available online at: http://eleconomista.com.mx/industrias/2011/04/06/acuerdan-mexico-peru-tlc-apertura-total-10-anos, last accessed 25 September 2013.

Murray, P. \& Moxon-Browne, E. (2013), "The European Union as a Template for Regional Integration? The case of ASEAN and its committee of permanent representatives", JCMS: Journal of Common Market Studies, 51(3): 522-537.

Oxford Analytica (2013), Latin America: Market integration brings cheap capital, Oxford: Oxford Analytica Ltd. (22 November, 2010). Retrieved from http://search.proquest.com/docview/807639236? accountid=45662, last accessed 25 September 2013.

Park, Y., Urata, S. \& Cheong, I. (2007), "The political economy of the proliferation of FTAs", In La Croix, S. \& Petri, P. Challenges to the global trading system: Adjustment to globalization in the Asia-Pacific region, New York: Routledge, pp. 43-57. 
Peña, C. \& Rozemberg, R. (2010), Una aproximación al desarrollo institucional del Mercosur: Sus fortalezas y debilidades, Washington: Inter-American Development Bank. Available online at: http://www.iadb.org/intal/intalcdi/ PE/2010/06593.pdf, last accessed 25 September 2013.

Proexport (2012), "ProChile, ProMéxico, PromPerú, Proinversión y Proexport firmaron declaración para fortalecer Alianza Pacífico", Colombian Agency for the Promotion of Trade, Investment and Tourism - Proexport (2012). Available online at: http://www.proexport.com.co/multimedia/ video/prochile-promexico-promperu-proinversion-y-proexport-firmaron-declaracion, last accessed 25 September 2013.

(2013), "Presentación Foro Alianza del Pacífico: Un camino por andar. Oportunidades para Colombia", Colombian Agency for the Promotion of Trade, Investment and Tourism - Proexport. Available online at: http:// www.proexport.com.co/sites/default/files/flash/presentacion_foro_republica_alianza_pacifico/index_2.html, last accessed 25 September 2013.

Richardson, M. (1993), “Endogenous protection and trade diversion”, Journal of International Economics, No. 34, pp. 309-324.

Rodrik, D. (2000), "How far will international economic integration go?", The Journal of Economic Perspectives, 14(1): 178-186.

Roldán Pérez, A. (2010), Beneficios y retos de Colombia en APEC, Medellín: Fondo Editorial Universidad EAFIT.

Santiso, J. (2008), "La emergencia de las Multilatinas", Revista de la CEPAL, No. 95, pp. 7-30.

- - (2013), The Decade of the Multilatinas, New York: Cambridge University Press.

Schiavon, J. A. \& Velásquez Flores, R. (2012), La política exterior de México 2012-2018: Diagnóstico y propuestas, México, DF: Asociación Mexicana de Estudios Internacionales, A. C.

Secretaría de Economía (2013), Secretaría de Economía de México. Available online at: http://www.economia.gob.mx/, last accessed 25 September 2013. SICE-OAS (2013), Foreign Trade Information System of the Organization of American States. Available online at: http://www.sice.oas.org/, last accessed 25 September 2013.

Sohn, C. \& Lee, H. (2010), "Trade Structure, FTAs, and Economic Growth", Review of Development Economics, No. 14, pp. 683-698.

SRe México (2013), Papel de México en la integración de América Latina y el Caribe: Creación de la Comunidad de Estados Latinoamericanos y Caribeños 
- Libro Blanco, México: Secretaría de Relaciones Exteriores de México (2010). Available online at: http://www.sre.gob.mx/images/stories/ doctransparencia/rdc/4lbcelac.pdf, last accessed 25 September 2013.

UnCTAD (2010), Integración regional en América Latina: Desafíos y oportunidades, New York: United Nations Conference on Trade and Development.

- - (2013), "Global Value Chain and Development: Investment and Value Added Trade in the Global Economy", United Nations Conference on Trade and Development, Geneva. Available online at: http://unctad.org/en/PublicationsLibrary/diae2013d1_en.pdf, last accessed 25 September 2013.

UnCTADstat (2013), Exports and imports of goods and services, annual, 19802012. Available online at: http://unctadstat.unctad.org/TableViewer/ tableView.aspx, last accessed 25 September 2013.

Vargas-Alzate, L. F., Sosa, S. \& Rodríguez-Ríos, J. D. (2012), "El comercio como plataforma de la política exterior colombiana en la administración de Juan Manuel Santos”, Colombia Internacional, No. 76, pp. 259-292.

Vargas-Hidalgo, R. (1979), "The crisis of the Andean Pact: Lessons for integration among developing countries", Journal of Common Markets Studies, 17(3): 213-226.

Villarreal, M. A. (2012), "Mexico's Free Trade Agreements", Congressional Research Service. Available online at: http://www.fas.org/sgp/crs/row/ R40784.pdf, last accessed 25 September 2013.

Wто (2011), "World Trade Report 2011: The Wто and preferential trade agreements: From co-existence to coherence", World Trade Organization (2011). Available online at: http://www.wto.org/english/res_e/booksp_e/ anrep_e/world_trade_report11_e.pdf, last accessed 25 September 2013. 


\section{YUSUKE MURAKAMI}
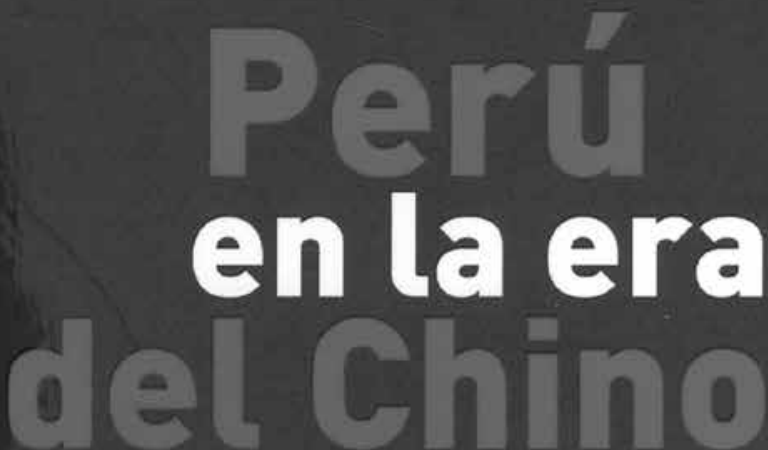

La política no institucionalizada y el pueblo en busca de un salvador

Segunda edición

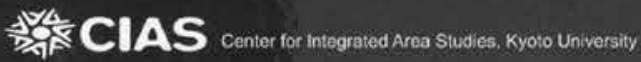

IEP Instituto de Estudios Peruanos 